\title{
PERSEPSI APARATUR PEMERINTAH DESA TERHADAP DANA DESA DI KECAMATAN SELUMA BARAT KABUPATEN SELUMA
}

\author{
Ahmad Soleh \\ Feri Susanto \\ Reka Susanti \\ Program Studi Akuntansi Fakultas Ekonomi Universitas Dehasen Bengkulu \\ ahmadsolehse81@yahoo.co.id
}

\begin{abstract}
ABSTRAK
Ahmad Soleh, Feri Susanto, Reka Susanti; Persepsi arapatur pemerintah desa terhadap dana desa di Kecamatan Seluma Barat Kabupaten Seluma. Persepsi aparatur pemerintah desa akan mempengaruhi kegiatan dalam penggunaan dana desa. Tujuan dari penelitian ini adalah untuk mengetahui persepsi aparatur pemerintah desa terhadap dana desa di kecamatan Seluma Barat kabupaten Seluma. Penentuan sampel dalam penelitian ini menggunakan purposive sampling. Sampel dalam penelitian ini sebanyak 36 orang yakni Kepala Desa, Sekretaris, Bendahara, dan ketua BPD yang menjabat sebagai aparatur pemerintah desa dari 9 (Sembilan) desa yang berada di Kecamatan Seluma Barat Kabupaten Seluma. Kesembilan desa tersebut meliputi desa Talang Perapat, desa Purbosari, desa Air Latak, desa Pagar Agung, desa Talang Tinggi, desa Lunjuk, desa Sengkuang, desa Tanjung Agung, dan desa Lubuk Lagan. Rating Scale digunakan dalam menganalisis data yang diperoleh dengan menggunakan kuesioner. Hasil penelitian menunjukkan bahwa persepsi aparatur pemerintah desa terhadap kegiatan penyelenggaraan pemerintahan desa menunjukkan interpretasi yang baik (71,8 \%); persepsi aparatur pemerintah desa terhadap kegiatan pembangunan dan perbaikan infrastruktur desa menunjukkan interpretasi yang sangat baik (88,6 \%); persepsi aparatur pemerintah desa terhadap kegiatan pemberdayaan masyarakat menunjukkan interpretasi yang sangat baik (85,4\%); dan persepsi aparatur pemerintah desa terhadap kegiatan kemasyarakatan menunjukkan interpretasi yang sangat baik $(81,2 \%)$.
\end{abstract}

\begin{abstract}
Ahmad Soleh, Feri Susanto, Reka Susanti; Perception of the village government's arapatur to the village fund in Seluma Barat Sub-district of Seluma District. The perception of the village government apparatus will affect activities in the use of village funds. The purpose of this research is to know the perception of village government apparatus to village fund in Seluma Barat sub-district of Seluma district. Determination of samples in this study using Purposive sampling. The sample in this research are 36 people, namely the Village Head, Secretary, Treasurer, and the head of BPD who served as the village government apparatus from 9 (Nine) villages in Seluma Barat District Seluma District. The nine villages include Talang Perapat village, Purbosari village, Air Latak village, Pagar Agung village, Talang Tinggi village, Lunjuk village, Sengkuang village, Tanjung Agung village and Lubuk Lagan village. Rating Scale is used in analyzing data obtained by using questionnaires. The results showed that the perception of the village government apparatus on village governance activities showed good interpretation (71.8\%); Perceptions of village government apparatuses towards development activities and improvements in village infrastructure show excellent interpretation (88.6\%); Perceptions of village government apparatuses on community empowerment activities showed excellent interpretation (85.4\%); And perception of village government apparatus towards social activities showed excellent interpretation (81,2\%).
\end{abstract}

Key Words: Perceptions of the Village Government Apparatus, Village Funds, Seluma Barat District, Seluma District

\section{LATAR BELAKANG}

Desa merupakan kesatuan masyarakat hukum yang memiliki batas-batas wilayah yang berwenang untuk mengatur dan mengurus kepentingan masyarakat setempat, berdasarkan asal usul dan adat istiadat setempat yang diakui dan dihormati dalam sistem pemerintahan Negara Kesatuan Republik Indonesia (NKRI). Untuk mengatur dan mengurus kepentingan masyarakat desa dikepalai oleh kepala desa yang dibantu oleh perangkat desa seperti sekretaris, bendahara, kepala dusun, rukun tetangga, dan rukun warga. 
Kepala desa mempunyai tugas menyelenggarakan pemerintahan desa, melaksanakan pembangunan desa, pembinaan kemasyarakatan desa, dan pemberdayaan masyarakat desa. Menurut undang-undang nomor 17 tahun 2003 tentang keuangan negara, bahwa dalam upaya penyelenggaraan pemerintahan, pelaksanaan pembangunan, pembinaan kemasyarakatan, dan pemberdayaan masyarakat suatu desa memiliki anggaran atau dana yang disebut keuangan desa. Keuangan desa adalah semua hak dan kewajiban desa yang dapat dinilai dengan uang serta segala sesuatu baik berupa uang maupun barang yang berhubungan dengan pelaksanaan hak dan kewajiban desa. Dengan adanya keuangan desa ini diharapkan tiap desa mampu untuk memperkuat daerah-daerah dan desa dalam kerangka Negara Kesatuan Republik Indonesia (NKRI).

Undang-undang RI Nomor 6 tahun 2014 tentang desa menegaskan bahwa pembangunan desa merupakan tanggung jawab desa itu sendiri. Di Bab I, Pasal 4, poin I menyatakan bahwa desa adalah subjek pembangunan. Selain itu, di pasal 18 terdapat kewenangan kepala desa dalam mengkoordinasikan pembangunan desa secara partisipatif yang bertujuan mewujudkan desa mandiri energi, desa mandiri benih dan desa mandiri pangan. Membangun Indonesia dari pinggiran yaitu melalui desa menyebabkan daerah menjadi titik sentral pembangunan. Pembangunan ini bisa dilakukan dengan adanya alokasi dana dari pemerintah yang disebut dengan dana desa. Alokasi Dana Desa (ADD) yang disiapkan oleh pemerintah diatur dalam Peraturan Menteri Keuangan (PMK) Nomor 49/PMK.07/2016 Tentang tata cara pengalokasian, penyaluran, pemantauan, dan evaluasi dana desa. Dana desa yang telah ditetapkan dalam Anggaran Pendapatan dan Belanja Negara (APBN) tahun 2016 adalah sebesar Rp. 46,9 triliun. Dana desa akan disalurkan dalam dua tahap, yaitu pada bulan Maret dan Agustus 2016. Penyaluran dalam dua tahap tersebut dilakukan sesuai dengan Peraturan Menteri Keuangan (PMK) Nomor 49/PMK.07/2016 Tentang tata cara pengalokasian, penyaluran, penggunaan, pemantauan, dan evaluasi dana desa. Payung hukum tersebut merupakan turunan dari Peraturan Pemerintah (PP) Nomor 8 tahun 2016 tentang perubahan kedua atas PP Nomor 60 Tahun 2014 tentang dana desa yang bersumber dari Anggaran Pendapatan dan Belanja Negara (APBN) dimana dana desa yang akan diterima tiap desa pada tahun 2016 ini rata-rata sebesar Rp. 600 juta dan pada tahun 2017 setiap desa diperkirakan akan mendapat dana Rp. 1,4 miliar.

Dalam Permendes Nomor 8 tahun 2016 tentang penetapan prioritas penggunaan dana desa harus didasarkan pada prinsip-prinsip keadilan, kebutuhan, dan tipologi desa. Tipologi desa sendiri didasarkan pada kekerabatan, desa, hamparan, pola pemukiman, mata pencaharian, dan tingkat perkembangan kemajuan desa. Penggunaan dan pengolahan dana desa untuk sementara hanya untuk pembangunan infrastruktur dan pelayanan dasar. Penggunaan dana desa untuk kegiatan yang lain setelah sarana prasarana masyarakat desa terpenuhi. Selain itu, pelaksanaan dana desa juga harus secara swakelola, padat karya, dan menggunakan bahan baku lokal sehingga bisa dinikmati oleh masyarakat desa setempat. oleh karena itu desa harus bisa membuat perencanaan sendiri untuk dilaksanakan sendiri dan diawasi oleh masyarakat desa itu sendiri.

Kecamatan Seluma Barat kabupaten Seluma sebagai salah satu daerah yang menerima dana desa berdasarkan dari tipologi desa yang diatur dalam Permendes No 8 Tahun 2016 berdasarkan pada kekerabatan termasuk dalam desa campuran, berdasarkan hamparan termasuk dalam desa dataran rendah/lembah, berdasarkan pola pemukiman termasuk dalam desa memanjang, berdasarkan pola mata pencaharian termasuk dalam desa pertanian, dan berdasarkan tingkat perkembangan kemajuan desa termasuk dalam desa berkembang. Di kecamatan Seluma Barat kabupaten Seluma dana desa yang diterima digunakan dalam penyelenggaraan pemerintah desa, pembangunan dan perbaikan infrastruktur, pemerdayaan masyarakat dan kegiatan kemasyarakatan. APBDes kecamatan Seluma Barat kabupaten Seluma tahun 2016 sejumlah Rp 8.983.913.745,-. Adapun alokasi dana tersebut sebagaimana ditunjukkan pada gambar 1. Dari gambar 1 dapat dijelaskan bahwa alokasi penggunaan dana terbesar pada kegiatan pembangunan dan perbaikan infrastruktur mencapai Rp 6.225.477.677,- atau sebesar 69,29 \%. Dana tersebut dialokasikan pada kegiatan pemenuhan kebutuhan dasar, kegiatan pembangunan sarana dan prasarana desa, dan kegiatan pengembangan potensi ekonomi. Alokasi penggunaan dana terbesar ke dua pada kegaiatan penyelenggaraan pemerintah desa mencapai Rp 2.109.610.468,- atau sebesar 23,48 \%. Dana tersebut dialokasikan untuk belanja pegawai, operasioanal perkantoran, operasioanal BPD, operasioanal RT/RW, dan penyelenggaraan kegiatan. Alokasi penggunaan dana untuk kegiatan kemasyarakatan sebesar Rp 332.102.766,-- atau sebesar 3,70 \%. Dana tersebut dialokasikan untuk kegiatan pembinaan lembaga kemasyarakatan, kegiatan penyelenggarakan ketentraman dan ketertiban, kegiatan pembinaan kerukunan umat beragama, kegiatan pengadaan sarana dan prasarana olah raga, kegiatan pembinaan lembaga adat, kegiatan pembinaan kesenian dan sosial budaya masyarakat, dan kegiatan pembinaan kemasyarakatan lainnya. Selanjutnya alokasi penggunaan dana untuk kegiatan pemerdayaan masyarakat sebesar Rp 316.722.834,- atau sebesar 3,52 \%. Dana tersebut dialokasikan untuk kegiatan peningkatan kualitas proses perencanaan desa, kegiatan pendukung kegiatan ekonomi baik yang 
dikembangkan oleh BUM Desa maupun kelompok usaha masyarakat desa lainnya, kegiatan pembentukan dan peningkatan kapasitas kader pemberdayaan masyarakat desa, kegiatan pengorganisasian melalui pembentukan dan fasilitasi paralegal untuk memberikan bantuan hukum kepada warga masyarakat desa, kegiatan penyelenggaraan promosi kesehatan dan gerakan hidup bersih dan sehat, kegiatan dukungan terhadap kegiatan desa dan masyarakat pengelolaan hutan desa dan hutan kemasyarakatan, kegiatan peningkatan kapasitas kelompok masyarakat, dan kegiatan pemberdayaan masyarakat lainnya.

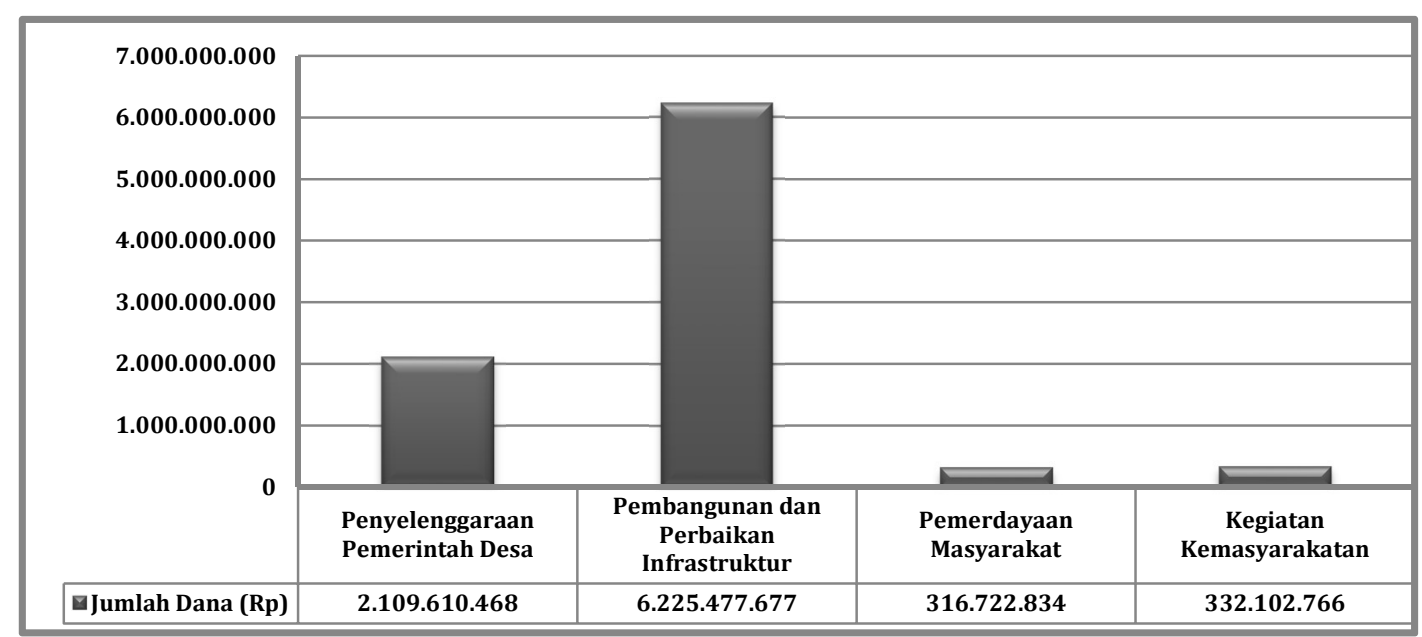

Sumber: Kecamatan Seluma Barat, 2016

Gambar 1. APBDes Kecamatan Seluma Barat Kabupaten Seluma Tahun 2016.

Dalam UU Desa, dan peraturan terkait lainnya dengan tegas menyebutkan, bahwa Pengelolaan Keuangan Desa harus dilakukan secara transpran, akuntabel, partisipatif, serta tertib dan disiplin anggaran. Aparatur pemerintah desa memiliki peran yang tinggi dalam pengelolaan dana desa dalam pelaksanaan pembangunan. Sejumlah permasalahan yang sering ditemukan selama ini. Masih banyak desa yang belum benar-benar siap untuk menerapkan UU Desa tersebut. Selanjutnya dari sisi kemampuan kepala desa dengan jajarannya belum mumpuni. Berdasar pada latar belakang dan permasalahan di atas, analisis persepsi arapatur pemerintah desa terhadap dana desa di Kecamatan Seluma Barat Kabupaten Seluma sangat penting untuk dilakukan.

\section{LANDASAN TEORI Pengertian Desa}

Dalam Kamus Besar Bahasa Indonesia (KBBI), kata "desa" sendiri berasal dari bahasa India yakni "swadesi" yang berarti tempat asal, tempat tinggal, negeri asal, atau tanah leluhur yang merujuk pada suatu kesatuan hidup, dengan satu kesatuan norma, serta memiliki batas yang jelas. Desa merupakan suatu daerah hukum yang merupakan wilayah masyarakat hukum terbentuk atas dasar ikatan tertentu, antara lain bentuk genealogis, bentuk territorial, dan bentuk campuran keduanya. Menurut Undang-Undang Nomor 6 Tahun 2014 Tentang Desa, ditentukan bahwa desa adalah desa dan desa adat atau yang disebut dengan nama lain, selanjutnya disebut desa, adalah kesatuan masyarakat hukum yang memiliki batas wilayah yang berwenang untuk mengatur dan mengurus urusan pemerintahan, kepentingan masyarakat, hak asal-usul, dan atau hak tradisonal yang diakui dan dihormati dalam sistem pemerintahan Negara Kesatuan Republik Indonesia.

\section{Aparatur Pemerintah Desa}

Dalam Permendagri No 82 Tahun 2015 tentang pengangkatan dan pemberhentian kepala desa, pemerintahan desa adalah penyelenggaraan urusan pemerintahan dan kepentingan masyarakat setempat dalam sistem pemerintahan Negara Kesatuan Republik Indonesia. Pemerintah desa adalah kepala desa atau yang disebut dengan nama lain dibantu perangkat desa sebagai unsur penyelenggara pemerintah desa. Dengan demikian dapat dikatakan bahwa aparat desa meliputi semua orang yang terlibat dalam urusan pemerintahan desa. Aparatur desa antara lain:

1. Kepala Desa

Kepala desa adalah pemimpin dari desa di Indonesia. Kepala desa merupakan pimpinan dari pemerintah desa. Masa jabatan kepala desa adalah 6 tahun, dan dapat diperpanjang lagi untuk satu kali masa jabatan. Kepala desa tidak bertanggung jawab kepada camat, namun hanya dikoordinasikan saja oleh camat. Kepala desa diangkat dan diberhentikan oleh bupati/walikota setelah sejak diterima 
laporan hasil pemilihan kepala desa dari BPD. Menurut UU No 6 Tahun 2014 Tentang Desa pasal 26 ayat (1), Kepala desa mempunyai tugas menyelenggarakan pemerintahan desa, melaksanakan pembangunan desa, pembinaan kemasyarakatan desa, dan pemberdayaan masyarakat desa. Berdasarkan tugas tersebut kepala desa memiliki wewenang yang diatur dalam ayat (2) meliputi: (a) Memimpin penyelenggaraan desa; (b) Mengangkat dan memberhentikan perangkat desa; (c) Memegang kekuasaan pengelolaan keuangan dan asset desa; (d) Menetapkan peraturan desa; (e) Menetapkan anggaran pendapatan dan belanja desa; (f) Membina kehidupan masyarakat desa; (g) Membina ketentraman dan ketertiban masyarakat desa; (h) Membina dan meningkatkan perekonomian desa serta mengintegrasikannya agar mencapai perekonomian skala produktif untuk sebesar-besarnya kemakmuran masyarakat desa; (i) Mengembangkan sumber pendapatan desa; (j) Mengusulkan dan menerima pelimpahan sebagai kekayaan negara guna meningkatkan kesejahteraan masyarakat desa; (k) Memanfaatkan teknologi tepat guna; (l) Mengordinasikan pembangunan desa secara partisipatif; (m) Mewakili desa didalam dan diluar pengadilan atau menunjuk kuasa hukum untuk mewakilinya sesuai dengan ketentuan peraturan perundang-undangan; (n) Melaksanakan wewenang lain yang sesuai dengan ketentuan peraturan perundang-undangan.

2. Sekretaris Desa

Sekertaris desa merupakan ujung tombak pemerintahan desa yang melaksanakan tugas khususnya membantu kepala desa di bidang administrasi dan memberikan pelayanan teknis administratif kepada seluruh perangkat desa serta membantu kepala desa dalam menjalankan hak, wewenang dan kewajiban pimpinan pemerintah desa. Adapun tugas dari sekretaris desa meliputi (a) Menyusun dan melaksanakan kebijakan pengelolaan APBDesa; (b) Menyusun rancangan peraturan desa tentang APBDesa, peubahan APBDesa dan pertanggung jawaban pelaksanaan APBDesa; (c) Melakukan pengendalian terhadap pelaksanaan kegiatan yang telah ditetapkan dalam APBDesa; (d) Menyusun pelaporan dan pertanggung jawaban pelaksanaan APBDesa; (e) Melakukan verifikasi terhadap bukti-bukti penerimaan dan pengeluaran APBDesa.

3. Bendahara

Bendahara adalah unsur staf sekretariat desa yang membidangi urusan administrasi keuangan untuk menatausahakan keuangan desa. Bendahara memiliki tugas menerima, menyimpan, menyetorkan/membayar, menata usahakan, dan mempertanggung jawabkan penerimaan pendapatan desa dan pengeluaran pendapatan desa dalam rangka pelaksanaan APBDes.

\section{Dana Desa}

Menurut Soleh dan Rohmansjah (2014), dana desa atau keuangan desa didefinisikan sebagai semua hak dan kewajiban desa yang dapat dinilai dengan uang, serta segala sesuatu baik berupa uang maupun barang yang dapat dijadikan milik desa berhubung dengan pelaksanaan hak dan kewajiban tersebut. Keuangan desa atau dana desa merupakan sub sistem dari keuangan negara yang diatur dalam UndangUndang No 17 Tahun 2003 tentang keuangan negara. Berdasarkan PP No 43 tahun 2014 tentang peraturan pelaksanaan undang-undang nomor 6 tahun 2014 tentang desa, dana desa adalah dana yanag bersumber dari anggaran pendapatan dan belanja negara yang diperuntukkan bagi desa yang ditransfer melalui anggaran pendapatan dan belanja daerah kabupaten/kota dan digunakan untuk membiayai penyelenggaraan pemerintahan, pelaksanaan pembangunan, pembinaan kemasyarakatan, dan pemberdayaan masyarakat.

Dasar hukum dana desa diawali dengan adanya undang-undang No 6 tahun 2014 tentang desa, lalu diikuti dengan keluarnya PP No 43 tahun 2014 yang kemudian diperbaharui melalui PP No 47 tahun 2014 dan PP No 60 tahun 2014 tentang dana desa yang bersumber dari APBN yang kemudian diperbaharui menjadi PP No 22 tahun 2015. Selain Undang-Undang dan PP tersebut terdapat juga dasar hukum lain mengenai dana desa, yaitu:

1. Permendagri: (a) Permendagri No 111/20 14 tentang pedoman teknis peraturan di desa; (b) Permendagri No 112/2014 tentang pemilihan kepala desa; (c) Permendagri No 113/2014 tentang pengelolaan keuangan desa; (d) Permendagri No 114/2014 tentang pedoman pembangunan desa.

2. Permendes: (a) Permendes No 21 Tahun 2015 tentang penetapan prioritas penggunaan dandes 2016; (b) Permendes No 1 Tahun 2015 tentang pedoman kewenangan berdasarkan hak asal usul dan kewenangan lokal bersekala desa; (c) Permendes No 2 T/2015 tentang musyawarah desa.

3. PMK 247/PMK.7/2015 (mengatur hal-hal teknis terkait pengalokasian, penyaluran, penggunaan, pemantauan, dan evaluasi dana desa).

Ketentuan PP No 60 Tahun 2014 pasal 19 ayat (1), dana desa digunakan untuk membiayai penyelenggaraan pemerintahan, pembangunan, pemberdayaan masyarakat, dan kemasyarakatan. Penyelenggaraan pemerintahan yang dibiayai oleh dana desa meliputi kegiatan operasional pemerintahan 
dan penggajian perangkat desa, pembangunan yang dibiayai oleh dana desa adalah seluruh pembangunan infrastruktur desa yang dapat membantu kehidupan sosial ekonomi masyarakat desa. Kegiatan pemberdayaan masyarakat dan kemasyarakatan yang dibiayai dana desa meliputi pelatihan dan peningkatan kegiatan sosial ekonomi masyarakat desa. Sedangkan kegiatan pemberdayaan masyarakat dan kemasyarakatan yang dibiayai dana desa meliputi pelatihan dan peningkatan kegiatan sosial ekonomi masyarakat desa dan kegiatan pengamanan ketentraman dan ketertiban masyarakat desa, pengamanan nilai-nilai keagamaan, sosial budaya dalam masyarakat desa.

Sedangkan dalam pasal 20 penggunaan dana desa mengacu pada rencana pembangunan jangka menengah desa dan rencana kerja pemerintah desa. Penggunaan dana desa harus menggunakan prinsip:

1. Keadilan, dengan mengutamakan hak atau kepentingan seluruh warga desa tanpa membeda-bedakan.

2. Kebutuhan prioritas, dengan mendahulukan kepentingan desa yang lebih mendesak, lebih dibutuhkan dan berhubungan langsung dengan kepentingan sebagian besar masyarakat desa.

3. Tipologi desa, dengan mempertimbangkan keadaan dan kenyataan karakteristik geografis, sosiologis, antropologis, ekonomi, dan ekologi desa yang khas, serta perubahan atau perkembangan kemajuan desa.

4. Untuk meningkatkan kesejahteraan masyarakat desa dan kualitas hidup manusia serta penanggulangan kemiskinan, prioritas penggunaan dana desa diarahkan untuk pelaksanaan program dan kegiatan pembangunan desa yang meliputi: (a) Pembangunan, pengembangan, dan pemeliharaan infrastruktur atau sarana dan prasarana fisik untuk penghidupan, termasuk ketahanan pangan, dan pemukiman; (b) Pembangunan, pengembangan, dan pemeliharaan sarana dan prasarana kesehatan masyarakat; (c) Pembangunan, pengembangan dan pemeliharaan sarana dan prasarana pendidikan sosial dan kebudayaan; (d) Pengembangan usaha ekonomi masyarakat, meliputi pembangunan dan pemeliharaan sarana prasarana produksi dan distribusi; (e) Pembangunan dan pengembangan sarana prasarana energi terbarukan serta kegiatan pelestarian lingkungan hidup.

\section{Keuangan Desa}

Menurut Undang-Undang Nomor 6 Tahun 2014 Pasal 71 (1), keuangan desa adalah semua hak dan kewajiban desa yang dapat dinilai dengan uang serta segala sesuatu baik berupa uang maupun barang yang berhubungan dengan pelaksanaan hak dan kewajiban desa. Pengelolaan keuangan desa adalah keseluruhan kegiatan yang meliputi perencanaan, pelaksanaan, penatausahaan, pelaporan dan pertanggungjawaban keuangan desa. Dalam Permen No 113 Tahun 2014 tentang pengelolaan keuangan desa, keuangan desa dikelola berdasarkan asas-asas transparan, akuntabel, partisipatif serta dilakukan dengan tertib dan disiplin anggaran. Pengelolaan keuangan desa dikelola dalam masa 1 (satu) tahun anggaran yakni mulai tanggal 1 Januari sampai dengan 31 Desember.

\section{KERANGKA ANALISIS}

Agar memudahkan pemahaman dalam penelitian ini, maka perlu dibuat kerangka analisis seperti ditunjukkan pada gambar 2. Gambar 2 menjelaskan alur penelitian yakni menganalisis persepsi aparatur pemerintah desa terhadap dana desa khususnya tentang kegiatan penyelenggaraan pemerintah desa, kegiatan pembangunan dan perbaikan infrastruktur, kegiatan pemberdayaan masyarakat yang dilakukan, dan kegiatan kemasyarakatan yang dilakukan. Persepsi aparatur pemerintah desa mengacu pada UU No 6 Tahun 2014, PP No 60 dan PP No 43 Tahun 2014, Permendagri No 113 Tahun 2014, dan Permendes No 8 Tahun 2016. Sehingga akan diketahui penilaian indikator persepsi aparatur pemerintah desa pada empat kategori penilaian yakni sangat baik, baik, kurang baik, dan tidak baik.

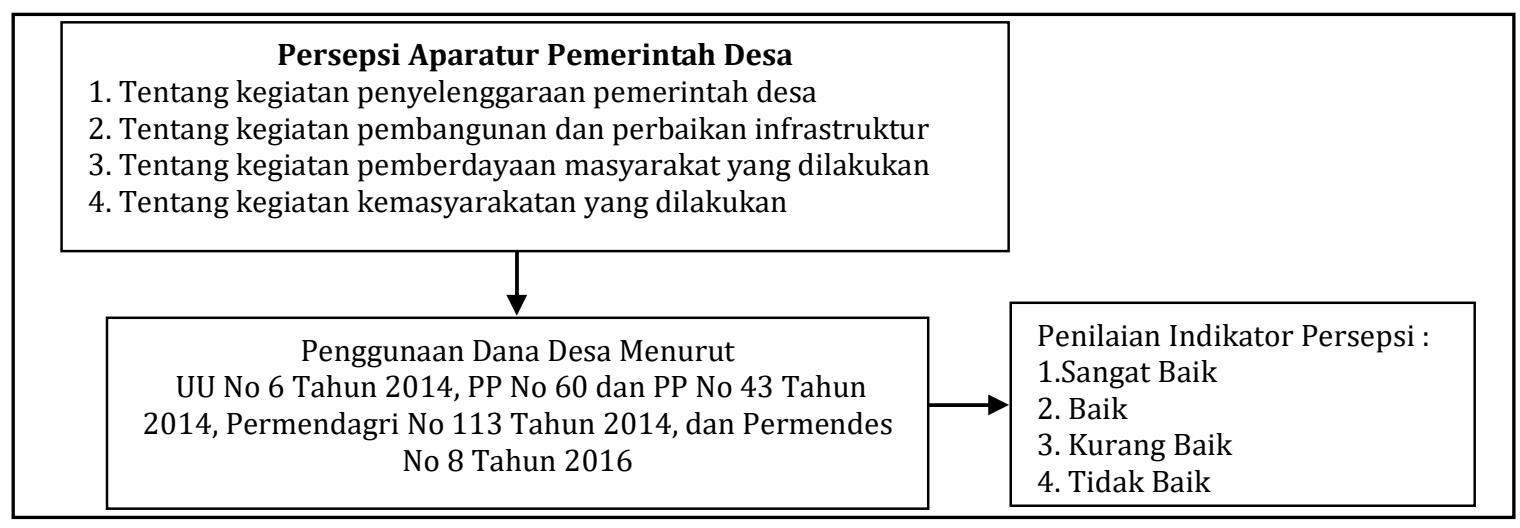

Gambar 2. Kerangka Analisis 


\section{METODOLOGI}

Penelitian ini menggunakan data primer. Penentuan sampel dalam penelitian ini menggunakan Purposive sampling. Sampel dalam penelitian ini sebanyak 36 orang yakni Kepala Desa, Sekretaris, Bendahara, dan ketua BPD yang menjabat sebagai aparatur pemerintah desa dari 9 (Sembilan) desa yang berada di Kecamatan Seluma Barat kabupaten Seluma. Kesembilan desa tersebut meliputi desa Talang Perapat, desa Purbosari, desa Air Latak, desa Pagar Agung, desa Talang Tinggi, desa Lunjuk, desa Sengkuang, desa Tanjung Agung, dan desa Lubuk Lagan. Rating Scale digunakan dalam menganalisis data yang diperoleh dengan menggunakan kuesioner. Skala rating scale ditunjukkan pada tabel berikut:

Tabel 1. Skala rating scale

\begin{tabular}{|c|c|}
\hline Interval Jawaban & Alternatif Jawaban \\
\hline 4 & Sangat Setuju \\
\hline 3 & Setuju \\
\hline 2 & Tidak Setuju \\
\hline 1 & Sangat Tidak Setuju \\
\hline
\end{tabular}

Sumber : Sugiyono (2012)

Skala Rating Scale tersebut menunjukkan arah yang positif, untuk menghitungnya maka data terlebih dahulu diubah lalu kemudian dihitung perhitungan rating scale dengan rumus (Sugiyono, 2012):

$\mathrm{P}=\frac{\text { Skor Pengumpulan Data }}{\text { Skor Ideal }} \times 100 \%$

Keterangan: $\mathrm{P}$ =angka persentase dan Skor ideal= skor tertinggi tiap butir $\mathrm{x}$ jumlah responden $\mathrm{x}$ jumlah butir. Rumus ini digunakan setelah data yang telah dikumpulkan pada angket yang berupa pernyataan Sangat Setuju (SS), Setuju (S), Tidak Setuju (TS), dan Sangat Tidak Setuju (STS) diubah kedalam bentuk angka yaitu angka 4 untuk jawaban Sangat Setuju (SS), angka 3 untuk jawaban Setuju (S), angka 2 untuk jawaban Tidak Setuju (TS), dan angka 1 untuk jawaban Sangat Tidak Setuju (STS). Angka yang diperoleh pada setiap item pernyataan menjadi skor pengumpulan data untuk pernyataan sedangkan sekor ideal merupakan skor tertinggi dari setiap pernyataan dikalikan dengan jumlah responden dan jumlah item pernyataan. Selanjutnya tingkat validasi dalam penelitian ini digolongkan dalam 4 kategori dengan skala yang dapat dilihat pada gambar 2 di bawah ini:

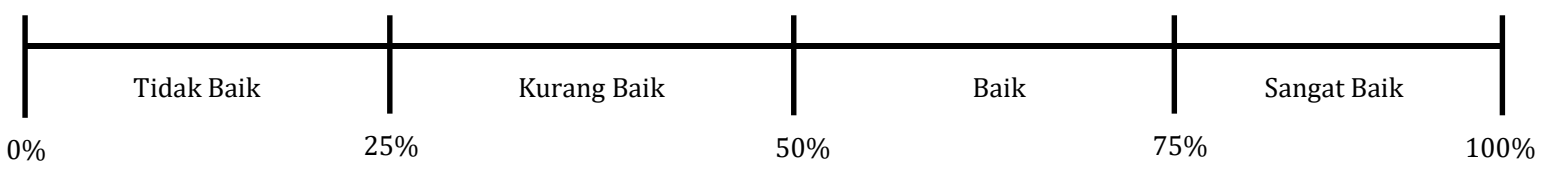

Gambar 3. Kategori skala nilai rating scale

\section{HASIL PENELITIAN DAN PEMBAHASAN}

Dalam penelitian ini, pengumpulan data dilakukan dengan melakukan penyebaran kuesioner terhadap sampel yang dipilih dengan menggunakan teknik purposive sampling. Sampel yang dipilih dalam penelitian ini merupakan perangkat desa dari 9 (Sembilan) desa yang ada di kecamatan Seluma Barat yaitu Kepala Desa, Bendahara, Sekretaris, dan ketua BPD. Adapun desa yang terdapat dalam kecamatan Seluma Barat yaitu Talang Tinggi, Lunjuk, Lubuk Lagan, Tanjung Agung, Pagar Agung, Air Latak, Talang Perapat, Purbosari dan Sengkuang. Hasil penelitian menunjukkan bahwa, karakteristik responden berdasar jenis kelamin menunjukkan bahwa $100 \%$ responden berjenis kelamin laki-laki. Selanjutnya karakteristik responden berdasar usia menunjukkan bahwa responden yang berusia antara 20-30 tahun sebanyak 8 orang (22,2\%); berusia antara 31-40 tahun sebanyak 12 orang (33,3\%); berusia antara 41-50 tahun sebanyak 14 orang $(38,9 \%)$; dan berusia $\geq 51$ tahun sebanyak 2 orang $(5,6 \%)$. Sedangkan jika dilihat dari tingkat pendidikan menunjukkan bahwa, responden dengan tingkat pendidikan SLTA sebanyak 27 orang (75\%); S1 sebanyak 4 orang (11,1\%); dan S2 sebanyak 1 orang $(2,8 \%)$. Pernyataan atas kuesioner yang diberikan kepada responden meliputi persepsi aparatur pemerintah desa terhadap dana desa khususnya tentang kegiatan penyelenggaraan pemerintah desa, kegiatan pembangunan dan perbaikan infrastruktur, kegiatan pemberdayaan masyarakat yang dilakukan, dan kegiatan kemasyarakatan. 


\section{Persepsi Aparatur Pemerintah Desa Tentang Kegiatan Penyelenggaraan Pemerintah Desa}

APBDesa kecamatan Seluma Barat dalam kegiatan penyelenggaraan pemerintah desa ditunjukkan pada tabel 2. Tabel 2 menunjukkan bahwa alokasi belanja pegawai pada APBDesa kecamatan Seluma Barat tahun 2016 memiliki porsi yang paling tinggi yakni mencapai Rp 1.654.900.000,- atau mencapai 78,45\% dati total dana yang dialokasikan untuk kegiatan penyelenggaraan pemerintah desa. Alokasi dana tersebut sebagian besar digunakan untuk membayar penghasilan tetap kepala desa dan perangkat yang mencapai Rp 982.800.000,- sedangkan selebihnya dialokasikan untuk tunjangan kepala desa dan perangkat serta tunjangan BPD. Dana penyelenggaran kegiatan memiliki porsi yang paling kecil yakni sebesar Rp 30.360.000,- yang akan digunakan untuk kegiatan penetapan dan penegasan batas data, pendataan desa/profil desa, penyelenggaraan perencanaan desa, dan penyelenggaraan kegiatan lainnya.

Tabel 2. Rincian dana kegiatan penyelenggaraan pemerintah desa

\begin{tabular}{|l|l|rr|}
\hline No & \multicolumn{1}{|c}{ Kegiatan } & \multicolumn{2}{c|}{ Rincian dana } \\
\hline & Bidang penyelenggaraan pemerintah desa & Rp & $\mathbf{2 . 1 0 9 . 6 1 0 . 4 6 8}$ \\
\hline 1 & Belanja pegawai & $\mathrm{Rp}$ & 1.654 .900 .000 \\
\hline & Penghasilan tetap kepala desa dan perangkat & $\mathrm{Rp}$ & 982.800 .000 \\
\hline & Tunjangan kepala desa dan perangkat & $\mathrm{Rp}$ & 108.000 .000 \\
\hline & Tunjangan BPD & $\mathrm{Rp}$ & 564.100 .000 \\
\hline 2 & Operasional perkantoran & $\mathrm{Rp}$ & 349.335 .468 \\
\hline & Belanja barang dan jasa & $\mathrm{Rp}$ & 211.969 .229 \\
\hline & Belanja modal & $\mathrm{Rp}$ & 137.366 .239 \\
\hline 3 & Operasional BPD & $\mathrm{Rp}$ & 66.515 .000 \\
\hline & Belanja barang dan jasa & $\mathrm{Rp}$ & 66.515 .000 \\
\hline 4 & Operasional RT/RW & $\mathrm{Rp}$ & 8.500 .000 \\
\hline & Belanja barang dan jasa & $\mathrm{Rp}$ & 8.500 .000 \\
\hline 5 & Penyelenggaraan kegiatan & $\mathrm{Rp}$ & 30.360 .000 \\
\hline & Penetapan dan penegasan batas data & $\mathrm{Rp}$ & 3.075 .000 \\
\hline & Pendataan desa/profil desa & $\mathrm{Rp}$ & 5.775 .000 \\
\hline & Penyelenggaraan perencanaan desa & $\mathrm{Rp}$ & 21.060 .000 \\
\hline & Penyelenggaraan kegiatan lainnya & $\mathrm{Rp}$ & 450.000 \\
\hline
\end{tabular}

Sumber : APBDes Kecamatan Seluma Barat, 2016

Persepsi aparatur pemerintah desa tentang kegiatan penyelenggaraan pemerintah desa di kecamatan Seluma Barat kabupaten Seluma ditunjukkan pada tabel 3.

Tabel 3. Persepsi aparatur pemerintah desa tentang kegiatan penyelenggaraan pemerintah desa

\begin{tabular}{|c|c|c|c|c|c|c|}
\hline \multirow{2}{*}{ No } & \multirow{2}{*}{ Pernyataan } & \multicolumn{4}{|c|}{ Nilai } & \multirow{2}{*}{ Jumlah } \\
\hline & & STS & TS & $\mathbf{S}$ & SS & \\
\hline 1 & $\begin{array}{l}\text { Dana desa digunakan dalam kegiatan operasional } \\
\text { pemerintahan }\end{array}$ & 4 & 14 & 16 & 2 & 88 \\
\hline 2 & $\begin{array}{l}\text { Dana desa digunakan dalam menjalankan kegiatan yang telah } \\
\text { dirancangkan dalam APBDesa }\end{array}$ & - & - & 11 & 25 & 133 \\
\hline 3 & $\begin{array}{l}\text { Dana desa digunakan untuk pembiayaan penggajian } \\
\text { perangkat desa }\end{array}$ & 3 & 11 & 16 & 6 & 97 \\
\hline 4 & Dana desa digunakan untuk tunjangan BPD & 2 & 9 & 17 & 5 & 94 \\
\hline \multirow[t]{2}{*}{5} & Dana desa digunakan sebagai peningkatan kantor desa/listrik & 2 & 6 & 21 & 7 & 105 \\
\hline & Jumlah & & & & & 517 \\
\hline
\end{tabular}

Sumber : hasil penelitian (data diolah), 2016.

Tabel 3 menunjukkan bahwa persepsi aparatur pemerintah desa di kecamatan Seluma Barat kabupaten Seluma sebagian besar sangat setuju dan setuju jika dana desa digunakan dalam menjalankan kegiatan yang telah dirancangkan dalam APBDesa (133). Hal ini menunjukkan bahwa aparatur pemerintah desa dalam pelaksanaan pengelolaan dana desa sesuai dengan rencana yang telah ditetapkan. Sedangkan persepsi atau penilaian terendah jika dana desa digunakan dalam kegiatan operasional pemerintahan (88). Terdapat $50 \%$ responden tidak setuju (14 orang) dan bahkan sangat tidak setuju (4 orang). Hal ini disebabkan kurangnya pemahaman aparatur pemerintah desa dalam memahami konsep keuangan desa. Responden tidak setuju karena menurut mereka sumber dana untuk kegiatan operasional desa berasal dari 
keuangan desa. Sedangkan sebagaimana diketahui bahwa keuangan desa merupakan satu kesatuan dengan dana desa, karena dana desa termasuk dalam keuangan desa.

Berdasar tabel 3 selanjutnya dapat diketahui nilai persentase atas persepsi aparatur pemerintah desa tentang kegiatan penyelenggaraan pemerintah desa yakni sebesar $71,8 \%$. Hal ini menunjukkan bahwa persepsi aparatur pemerintah desa terhadap kegiatan penyelenggaraan pemerintahan desa menunjukkan interpretasi yang baik. Kategori skala nilai rating scale kegiatan penyelenggaraan pemerintah desa bagi aparatur pemerintah desa di kecamatan Seluma Barat kabupaten Seluma seperti ditunjukkan pada gambar 4.

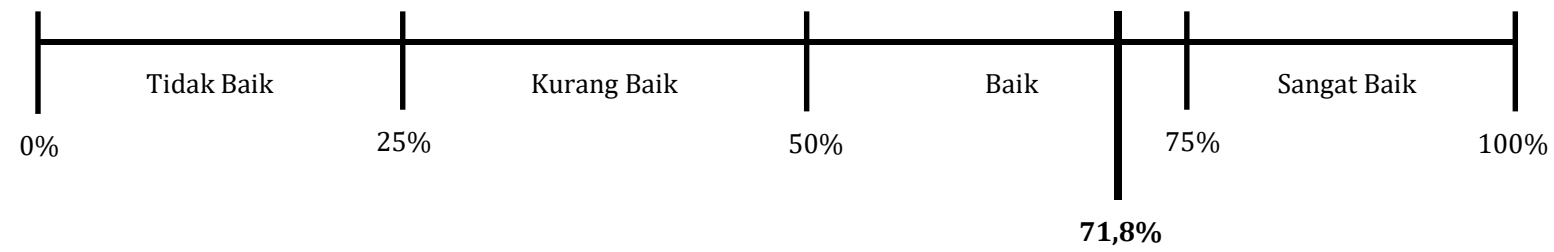

Gambar 4. Kategori skala nilai rating scale persepsi aparatur pemerintah desa terhadap kegiatan penyelenggaraan pemerintahan desa di kecamatan Seluma Barat Kabupaten Seluma.

Persepsi Aparatur Pemerintah Desa Tentang Kegiatan Pembangunan dan Perbaikan Infrastruktur APBDesa kecamatan Seluma Barat dalam kegiatan pembangunan dan perbaikan infrastruktur ditunjukkan pada tabel 4 . Tabel 4 menunjukkan bahwa alokasi kegiatan pembangunan sarana dan prasarana desa pada APBDesa kecamatan Seluma Barat tahun 2016 memiliki porsi yang paling tinggi yakni mencapai Rp 3.129.208.260,- atau mencapai 50,26\% dati total dana yang dialokasikan untuk kegiatan pembangunan dan perbaikan infrastruktur. Alokasi dana tersebut sebagian besar digunakan untuk pembangunan dan pemeliharaan jalan desa, mengingat sebagian besar infrastruktur jalan desa di kecamatan Seluma Barat dalam kondisi yang rusak dan memerlukan perbaikan guna kelancaran aktivitas ekonomi masyarakat. Selanjutnya, alokasi dana desa untuk kegiatan pemenuhan kebutuhan dasar juga tinggi yakni mencapai Rp 2.957.889.417,- atau mencapai 47,51\% dati total dana yang dialokasikan untuk kegiatan pembangunan dan perbaikan infrastruktur. Kegiatan pengembangan pos kesehantan desa polindes menjadi agenda yang sangat penting, hal tersebut tercermin pada alokasi dana desa yang tinggi yakni mencapai Rp 1.354.499.877,--.

Tabel 4. Rincian dana kegiatan pembangunan dan perbaikan infrastruktur

\begin{tabular}{|l|l|rr|}
\hline No & \multicolumn{1}{|c}{ Kegiatan } & \multicolumn{2}{c|}{ Rincian dana } \\
\hline & $\begin{array}{l}\text { Bidang pembangunan dan perbaikan infrastruktur/ } \\
\text { bidang pelaksanaan pembangunan desa }\end{array}$ & $\mathrm{Rp}$ & $\mathbf{6 . 2 2 5 . 4 7 7 . 6 7 7}$ \\
\hline 1 & Kegiatan pemenuhan kebutuhan dasar & $\mathrm{Rp}$ & 2.957 .889 .417 \\
\hline & Pengembangan pos kesehatan desa polindes & $\mathrm{Rp}$ & 1.354 .499 .877 \\
\hline & Pengelolah dan pembinaan posyandu & $\mathrm{Rp}$ & 267.497 .528 \\
\hline & Pembinaan dan pengelolaan pendidikan anak usia dini & $\mathrm{Rp}$ & 390.811 .298 \\
\hline & Pembangunan dan pemeliharaan sanitasi lingkungan & $\mathrm{Rp}$ & 413.558 .128 \\
\hline & Pembangunan dan pengelolaan air bersih berskala desa & $\mathrm{Rp}$ & 140.000 .000 \\
\hline & Taman bacaan masyarakat & $\mathrm{Rp}$ & 258.066 .836 \\
\hline & Balai pelatihan/kegiatan belajar masyarakat & $\mathrm{Rp}$ & 44.000 .000 \\
\hline & Sarana dan prasarana pendidikan dan pelatihan lainnya & $\mathrm{Rp}$ & 74.056 .750 \\
\hline & Sarana dan prasarana kesehatan lainnya & $\mathrm{Rp}$ & 15.399 .000 \\
\hline 2 & Kegiatan pembangunan sarana dan prasarana desa & $\mathrm{Rp}$ & 3.129 .208 .260 \\
\hline & Pembangunan dan pemeliharaan jalan desa & $\mathrm{Rp}$ & 1.377 .505 .449 \\
\hline & Pembangunan dan pemeliharaan jalan usaha tani & $\mathrm{Rp}$ & 733.956 .118 \\
\hline & Pembangunan dan pemeliharaan embung desa & $\mathrm{Rp}$ & 906.035 .906 \\
\hline & Pembangunan energi baru dan terbarukan (PLTMH, PLTS, & $\mathrm{Rp}$ & 108.236 .787 \\
\hline & Kincir Angin) & $\mathrm{Rp}$ & 3.474 .000 \\
\hline & Pembangunan sarana dan prasarana desa lainnya & $\mathrm{Rp}$ & 138.380 .000 \\
\hline 3 & Kegiatan pengembangan potensi ekonomi lokasi & $\mathrm{Rp}$ & 138.380 .000 \\
\hline & Pendirian dan pengembangan BUM Desa & &
\end{tabular}

Sumber : APBDes Kecamatan Seluma Barat, 2016

Persepsi aparatur pemerintah desa tentang kegiatan pembangunan dan perbaikan infrastruktur di kecamatan Seluma Barat kabupaten Seluma ditunjukkan pada tabel 5. 
Tabel 5. Persepsi aparatur pemerintah desa tentang kegiatan pembangunan dan perbaikan infrastruktur

\begin{tabular}{|c|l|c|c|c|c|c|}
\hline \multicolumn{1}{|c|}{ Pernyataan } & \multicolumn{3}{c|}{ Nilai } & \multicolumn{1}{c|}{ Jumlah } \\
\hline 1 & Anda mengetahui dengan pasti apa arti pembangunan & - & 1 & 10 & 25 & 132 \\
\hline 2 & $\begin{array}{l}\text { Pembangunan lebih kepada sektor fisik yaitu pembangunan } \\
\text { infrastruktur desa }\end{array}$ & - & - & 12 & 24 & 132 \\
\hline 3 & Dana desa memiliki dampak positif bagi pembangunan desa & - & - & 10 & 26 & 134 \\
\hline 4 & $\begin{array}{l}\text { Adanya peningkatan pembangunan infrastruktur } \\
\text { wilayah/desa secara bertahap }\end{array}$ & - & - & 18 & 18 & 126 \\
\hline 5 & $\begin{array}{l}\text { Kebijakan yang diambil oleh para pejabat kelurahan/desa } \\
\text { terhadap pembangunan desa sudah tepat }\end{array}$ & - & 2 & 26 & 8 & 114 \\
\hline & \multicolumn{1}{|c|}{ Jumlah } & & & $\mathbf{6 3 8}$ \\
\hline
\end{tabular}

Sumber : hasil penelitian (data diolah), 2016.

Tabel 5 menunjukkan bahwa sebagian besar aparatur pemerintah desa di kecamatan Seluma Barat memberikan persepsi setuju dan sangat setuju untuk setiap item pernyataan. Hal ini menunjukkan bahwa kebutuhan dasar atas sektor fisik berupa pembangunan infrastruktur desa perlu mendapat prioritas utama dan segera untuk diatasi. Persepsi aparatur pemerintah desa seiring dengan anggaran dana desa yang diperuntukkan untuk pembangunan infrastruktur desa yang mencapai nilai yang tinggi. Dampak positif dapat langsung dirasakan oleh masyarakat khususnya dalam memperlancar aktivitas ekonomi. Berdasar tabel 5 selanjutnya dapat diketahui nilai persentase atas persepsi aparatur pemerintah desa tentang kegiatan pembangunan dan perbaikan infrastruktur yakni sebesar 88,6\%. Hal ini menunjukkan bahwa persepsi aparatur pemerintah desa terhadap kegiatan pembangunan dan perbaikan infrastruktur menunjukkan interpretasi yang sangat baik. Kategori skala nilai rating scale kegiatan pembangunan dan perbaikan infrastruktur bagi aparatur pemerintah desa di kecamatan Seluma Barat kabupaten Seluma seperti ditunjukkan pada gambar 5 .

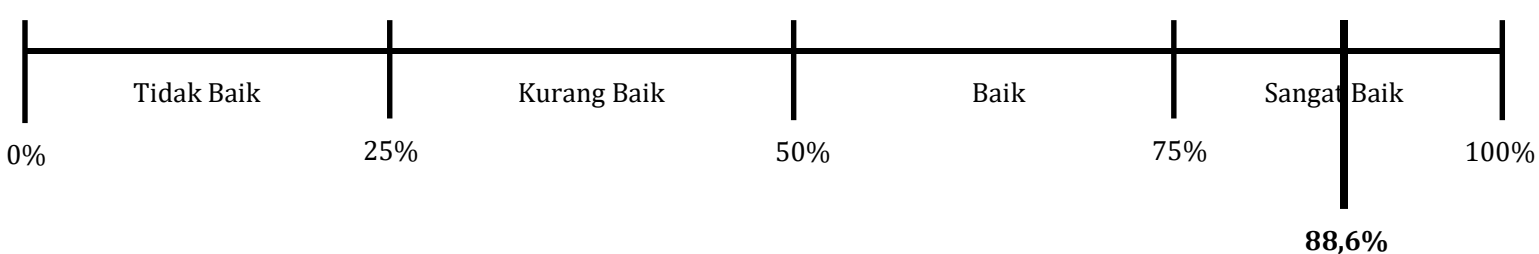

Gambar 5. Kategori skala nilai rating scale persepsi aparatur pemerintah desa terhadap kegiatan pembangunan dan perbaikan infrastruktur di kecamatan Seluma Barat Kabupaten Seluma.

\section{Persepsi Aparatur Pemerintah Desa Tentang Kegiatan Pemberdayaan Masyarakat}

Penggunaan dana desa di kecamatan Seluma Barat kabupaten Seluma juga diperuntukkan bagi kegiatan pemberdayaan masyarakat. Hal tersebut tercermin pada APBDesa kecamatan Seluma Barat dalam kegiatan pemberdayaan masyarakat yang ditunjukkan pada tabel 6.

Tabel 6. Rincian dana kegiatan pemberdayaan masyarakat

\begin{tabular}{|c|l|rr|}
\hline No & \multicolumn{1}{|c|}{ Kegiatan } & \multicolumn{1}{c|}{ Rincian dana } \\
\hline 1 & Bidang pemberdayaan masyarakat & Rp & $\mathbf{3 1 6 . 7 2 2 . 8 3 4}$ \\
\hline 2 & $\begin{array}{l}\text { Kegiatan peningkatan kualitas proses perencanaan desa } \\
\text { dikembangkan oleh BUM Desa maupun kelompok usaha } \\
\text { masyarakat desa lainnya }\end{array}$ & 123.624 .862 \\
\hline 3 & $\begin{array}{l}\text { Kegiatan pembentukan dan peningkatan kapasitas kader } \\
\text { pemberdayaan masyarakat desa }\end{array}$ & $\mathrm{Rp}$ & 74.485 .000 \\
\hline 4 & $\begin{array}{l}\text { Kegiatan pengorganisasian melalui pembentukan dan fasilitasi } \\
\text { paralegal untuk memberikan bantuan hukum kepada warga } \\
\text { masyarakat desa }\end{array}$ & $\begin{array}{l}\text { Rp } \\
\text { hegiatan penyelenggaraan promosi kesehatan dan gerakan }\end{array}$ & 13.499 .726 \\
\hline 5 & $\begin{array}{l}\text { Kegiatan dukungan terhadap kegiatan desa dan masyarakat } \\
\text { pengelolaan hutan desa dan hutan kemasyarakatan }\end{array}$ & $\mathrm{Rp}$ & 15.100 .000 \\
\hline 7 & Kegiatan peningkatan kapasitas kelompok masyarakat & $\mathrm{Rp}$ & 12.250 .000 \\
\hline 8 & Kegiatan pemberdayaan masyarakat lainnya & $\mathrm{Rp}$ & 300.000 \\
\hline
\end{tabular}

Sumber : hasil penelitian (data diolah), 2016. 
Besaran anggaran untuk kegiatan pemberdayaan masyarakat tidak sebesar alokasi dana yang diperuntukkan bagi kegiatan penyelenggaraan pemerintahan desa maupun kegiatan pembangunan dan perbaikan infrastruktur. Besaran alokasi dana untuk kegiatan ini pada tahun 2016 hanya sebesar Rp 316.722.834 yang terbagi dalam sembilan desa yang berada di kecamatan Seluma Barat kabupaten Seluma. Dalam anggaran kegiatan ini, alokasi dana terbesar pada kegiatan pendukung kegiatan ekonomi baik yang dikembangkan oleh BUM Desa maupun kelompok usaha masyarakat desa lainnya yang mencapai nilai Rp 123.663.244 atau sebesar 39\% dari alokasi dana desa untuk kegiatan pemberdayaan masyarakat. Selanjutnya persepsi aparatur pemerintah desa tentang kegiatan pemberdayaan masyarakat di kecamatan Seluma Barat kabupaten Seluma ditunjukkan pada tabel 7.

Tabel 7. Persepsi aparatur pemerintah desa tentang kegiatan pemberdayaan masyarakat

\begin{tabular}{|c|c|c|c|c|c|c|}
\hline \multirow{2}{*}{ No } & \multirow{2}{*}{ Pernyataan } & \multicolumn{4}{|c|}{ Nilai } & \multirow{2}{*}{ Jumlah } \\
\hline & & STS & TS & $\mathbf{S}$ & SS & \\
\hline 1 & $\begin{array}{l}\text { Dana desa digunakan untuk permodalan dalam peningkatan } \\
\text { ekonomi desa }\end{array}$ & - & 2 & 21 & 13 & 119 \\
\hline 2 & $\begin{array}{l}\text { Dana desa digunakan dalam fasilitasi dan kegiatan pelatihan } \\
\text { untuk masyarakat }\end{array}$ & - & 2 & 16 & 18 & 124 \\
\hline 3 & $\begin{array}{l}\text { Dana desa digunakan untuk peningkatan pengolahan edukasi } \\
\text { kesehatan masyarakat }\end{array}$ & - & - & 23 & 13 & 121 \\
\hline 4 & Dana desa digunakan untuk pelestarian lingkungan hidup & - & - & 19 & 17 & 125 \\
\hline \multirow[t]{2}{*}{5} & $\begin{array}{l}\text { Dana desa digunakan untuk program kegiatan ketahanan } \\
\text { pangan desa }\end{array}$ & - & - & 18 & 18 & 126 \\
\hline & Jumlah & & & & & 615 \\
\hline
\end{tabular}

Sumber : hasil penelitian (data diolah), 2016.

Berdasar tabel 7 dapat dijelaskan bahwa sebagian besar persepsi aparatur pemerintah desa setuju dan sangat setuju penggunaan dana desa bagi kegiatan pemberdayaan masyarakat. Penggunaan dana desa untuk program kegiatan ketahanan pangan desa menjadi agenda yang sangat penting. Mengingat sebagian besar penduduk di wilayah kecamatan Seluma Barat kabupaten Seluma menggantungkan perekonomian pada sektor pertanian (palawija) dan perkebunan (karet dan sawit). Sehingga program terkait dengan kegiatan ketahanan pangan menjadi sangat penting guna peningkatan produksi serta pengolahan hasil pertanian dan perkebunan. Selain itu, isu kelestarian lingkungan juga menjadi hal yang penting. Hal tersebut ditunjukkan dengan persepsi aparatur pemerintah desa yang tinggi atas penggunaan dana desa bagi pelestarian lingkungan hidup. Sedangkan persepsi atas penggunaan dana desa bagi kegiatan permodalan dalam peningkatan ekonomi desa relatif kecil. Hal tersebut dikhawatirkan penggunaan dana desa menjadi kurang produktif yang diakibatkan oleh terjadinya kemacetan kredit atau pinjaman yang diberikan.

Berdasar tabel 7 selanjutnya dapat diketahui nilai persentase atas persepsi aparatur pemerintah desa tentang kegiatan pemberdayaan masyarakat yakni sebesar 85,4\%. Hal ini menunjukkan bahwa persepsi aparatur pemerintah desa terhadap kegiatan pemberdayaan masyarakat menunjukkan interpretasi yang sangat baik. Kategori skala nilai rating scale pemberdayaan masyarakat bagi aparatur pemerintah desa di kecamatan Seluma Barat kabupaten Seluma seperti ditunjukkan pada gambar 6.

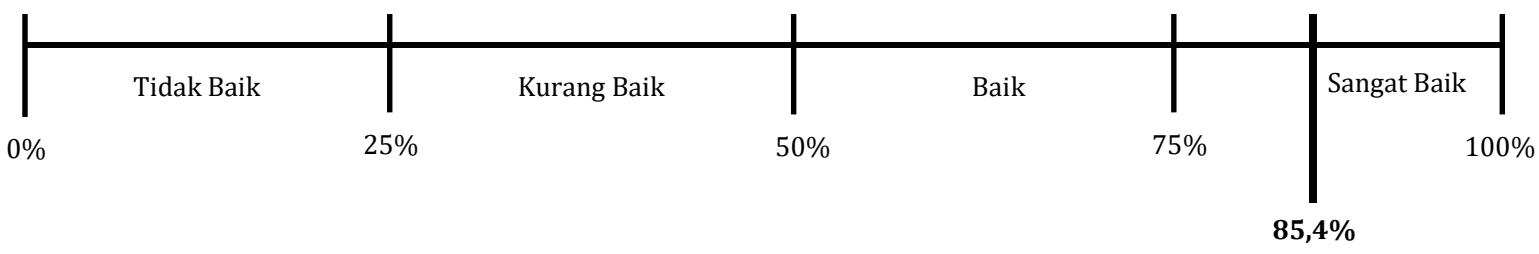

Gambar 6. Kategori skala nilai rating scale persepsi aparatur pemerintah desa terhadap kegiatan pemberdayan masyarakat di kecamatan Seluma Barat Kabupaten Seluma.

\section{Persepsi Aparatur Pemerintah Desa Tentang Kegiatan Kemasyarakatan}

Kegiatan kemasyarakatan menjadi agenda yang penting sehingga keberadannya diperhitungkan dalam penyusunan anggaran dana desa. APBDesa di kecamatan Seluma Barat Kabupaten Seluma tahun 2016, anggaran kegiatan ini sejumlah Rp 332.102.766. Besaran anggaran ini sedikit lebih tinggi jika dibanding dengan anggaran untuk kegiatan pemberdayaan masyarakat. Kegiatan pembinaan kerukunan umat beragama dan kegiatan penyelenggarakan ketentraman dan ketertiban merupakan dua kegiatan yang memiliki besaran anggaran yang relatif lebih tinggi jika dibanding dengan kegiatan lainnya. 
Tabel 8. Rincian dana kegiatan kemasyarakatan

\begin{tabular}{|l|llr|}
\hline No & \multicolumn{1}{|c|}{ Kegiatan } & \multicolumn{2}{c|}{ Rincian dana } \\
\hline & Bidang kemasyarakatan/pembinaan kemasyarakatan & Rp & $\mathbf{3 3 2 . 1 0 2 . 7 6 6}$ \\
\hline 1 & Kegiatan pembinaan lembaga kemasyarakatan & $\mathrm{Rp}$ & 26.890 .000 \\
\hline 2 & Kegiatan penyelenggarakan ketentraman dan ketertiban & $\mathrm{Rp}$ & 89.718 .266 \\
\hline 3 & Kegiatan pembinaan kerukunan umat beragama & $\mathrm{Rp}$ & 97.261 .000 \\
\hline 4 & Kegiatan pengadaan sarana dan prasarana olah raga & $\mathrm{Rp}$ & 37.750 .000 \\
\hline 5 & Kegiatan pembinaan lembaga adat & $\mathrm{Rp}$ & 38.810 .000 \\
\hline 6 & Kegiatan pembinaan kesenian dan sosial budaya masyarakat & $\mathrm{Rp}$ & 36.675 .500 \\
\hline 7 & Kegiatan pembinaan kemasyarakatan lainnya & $\mathrm{Rp}$ & 4.998 .000 \\
\hline
\end{tabular}

Sumber : hasil penelitian (data diolah), 2016.

Persepsi aparatur pemerintah desa tentang kegiatan kemasyarakatan di kecamatan Seluma Barat kabupaten Seluma ditunjukkan pada tabel 9. Sebagian besar aparatur pemerintah desa sangat setuju (20 orang) dan setuju (16 orang) bahwa penggunaan dana desa digunakan untuk meningkatkan pelayanan pada masyarakat desa dalam rangka pengembangan kegiatan sosial ekonomi masyarakat. Hal ini menujukkan bahwa masyarakat desa sangat membutuhkan peningkatan pelayanan yang baik khususnya dalam bidang sosial kemasyarakatan dan peningkatan ekonomi. Diperlukan berbagai strategi pengembangan kegiatan sosial ekonomi yang dapat membawa masyarakat desa keluar dari keterkungkungan dan keterbelakangan ekonomi. Selain itu, aparatur pemerintah desa juga memberikan persepsi yang tinggi atas penggunaan dana desa untuk mendorong peningkatkan keswadayaaan dan gotong royong masyarakat. Peningkatan sosial ekonomi masyarakat senantiasa diiringi dengan kearifan dan budaya lokal.

Tabel 9. Persepsi aparatur pemerintah desa tentang kegiatan kemasyarakatan

\begin{tabular}{|c|l|c|c|c|c|c|}
\hline No & \multicolumn{1}{|c|}{ Pernyataan } & STS & TS & S & SS & Jumlah \\
\hline 1 & $\begin{array}{l}\text { Dana desa digunakan untuk meningkatkan pengamanan nilai- } \\
\text { nilai keagamaan, sosial budaya dalam rangka mewujudkan } \\
\text { kesalehan sosial }\end{array}$ & - & 2 & 26 & 8 & 114 \\
\hline 2 & $\begin{array}{l}\text { Dana desa digunakan untuk mendorong peningkatkan } \\
\text { keswadayaaan dan gotong royong masyarakat }\end{array}$ & - & 1 & 16 & 19 & 126 \\
\hline 3 & $\begin{array}{l}\text { Dana desa digunakan untuk meningkatkan pelayanan pada } \\
\text { masyarakat desa dalam rangka pengembangan kegiatan sosial } \\
\text { ekonomi masyarakat }\end{array}$ & - & - & 16 & 20 & 128 \\
\hline 4 & $\begin{array}{l}\text { Dana desa digunakan untuk penyelenggaraan ketentraman } \\
\text { dan ketertiban masyarakat }\end{array}$ & - & 7 & 25 & 4 & 105 \\
\hline 5 & $\begin{array}{l}\text { Dana desa digunakan untuk kegiatan pembinaan yang } \\
\text { berhubungan dengan keagamaan, sosial, dan budaya }\end{array}$ & - & 10 & 12 & 14 & 112 \\
\hline & \multicolumn{1}{|c|}{ Jumlah } & & & $\mathbf{5 8 5}$ \\
\hline
\end{tabular}

Sumber : hasil penelitian (data diolah), 2016.

Berdasar tabel 9 selanjutnya dapat diketahui nilai persentase atas persepsi aparatur pemerintah desa tentang kegiatan kemasyarakatan yakni sebesar 81,2\%. Hal ini menunjukkan bahwa persepsi aparatur pemerintah desa terhadap kegiatan pemberdayaan masyarakat menunjukkan interpretasi yang sangat baik. Kategori skala nilai rating scale pemberdayaan masyarakat bagi aparatur pemerintah desa di kecamatan Seluma Barat kabupaten Seluma seperti ditunjukkan pada gambar 7.

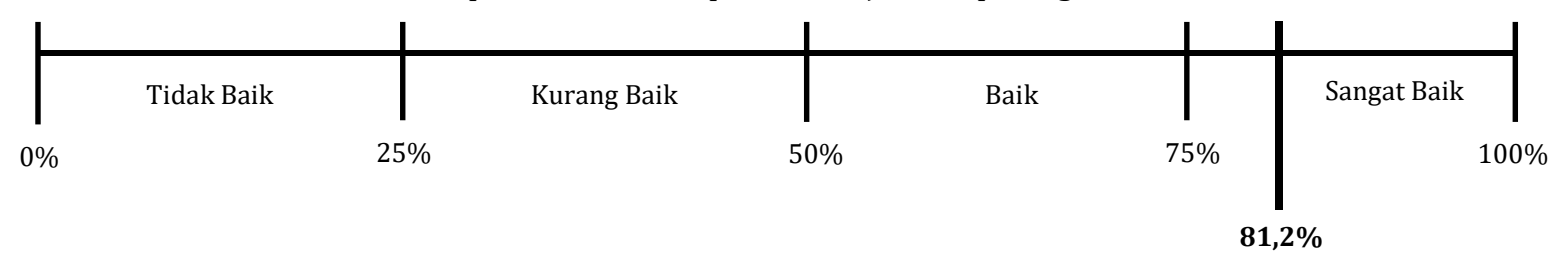

Gambar 7. Kategori skala nilai rating scale persepsi aparatur pemerintah desa terhadap kegiatan kemasyarakatan di kecamatan Seluma Barat Kabupaten Seluma. 


\section{KESIMPULAN}

Berdasar hasil penelitian dan pembahasan yang telah diuraikan di atas, maka penulis dapat menyimpulkan bahwa bahwa persepsi aparatur pemerintah desa terhadap kegiatan penyelenggaraan pemerintahan desa menunjukkan interpretasi yang baik hal tersebut ditunjukkan dengan nilai persentase atas persepsi yang diberikan sebesar 71,8\%. Selanjutnya persepsi aparatur pemerintah desa terhadap kegiatan pembangunan dan perbaikan infrastruktur desa, kegiatan pemberdayaan masyarakat, dan egiatan kemasyarakatan menunjukkan interpretasi yang sangat baik. Hal tersebut ditunjukkan dengan nilai persentase atas persepsi yang diberikan masing-masing secara berurutan sebesar 88,6\%; 85,4\%; dan $81,2 \%$. Rekomendasi yang diberikan khususnya bagi aparatur pemerintah desa dalam pengelolaan dana desa diantaranya adalah peningkatan pengetahuan dan pemahaman atas UU No 6 Tahun 2014, PP No 60 dan PP No 43 Tahun 2014, Permendagri No 113 Tahun 2014, dan Permendes terkait lainnya. Kurangnya pemahaman atas undang-undang dan aturan tersebut menyebabkan multi tafsir hingga kegagalan dalam pengelolaan dana desa bagi kemajuan desa dan kesejahteraan masyarakat.

\section{DAFTAR PUSTAKA}

APBDes Kecamatan Seluma Barat Kabupaten Seluma Tahun 2016.

Peraturan Pemerintah Republik Indonesia Nomor 60 Tahun 2014 Tentang Dana Desa yang Bersumber dari Anggaran Pendapatan dan Belanja Negara.

Peraturan Pemerintah Republik Indonesia Nomor 43 Tahun 2014 Tentang Peraturan Pelaksanaan UndangUndang Nomor 6 Tahun 2014 tentang Desa.

Peraturan Menteri Dalam Negeri Republik Indonesia Nomor 113 Tahun 2014 Tentang Pengelolaan Keuangan Desa.

Peraturan Menteri Dalam Negeri Republik Indonesia Nomor 82 Tahun 2015 Tentang Pengangkatan Dan Pemberhentian Kepala Desa.

Peraturan Menteri Desa, Pembangunan Daerah Tertinggal, Dan Transmigrasi Republik Indonesia Nomor 8 Tahun 2016 Tentang Perubahan atas Peraturan Menteri Desa, Pembangunan Daerah Tertinggal, Dan Transmigrasi Republik Indonesia No. 21 Tahun 2015 Tentang Penetapan Prioritas Penggunaan Dana Desa Tahun 2016.

Peraturan Menteri Keuangan Republik Indonesia Nomor 49/PMK.07/2016 Tentang Tata Cara Pengalokasian, Penyaluran, Pemantauan, Penggunaan Dan Evaluasi Dana Desa.

Soleh, Chabib dan Rochmansjah, Heru. 2014. Pengelolaan Keuangan Desa. Focus Media, Bandung.

Sugiyono. 2012. Metode Penelitian Kuantitatif, Kualitatif, R\&D. Alfabeta, Bandung.

Undang-Undang Nomor 17 Tahun 2003 Tentang Keuangan Negara.

Undang-Undang Republik Indonesia Nomor 6 Tahun 2014 Tentang Desa. 